\title{
Investigation of Selected Heavy Metal lons in Irrigation Water, Soil and Managu (Solanum Nigrum) from Homahills, Homabay County, Kenya
}

\author{
Teresa Akenga ${ }^{1}$, Emmy Kerich ${ }^{2,}$, Ayabei Kiplagat ${ }^{3}$, Vincent Sudoi $^{2}$, Cyrus Kuya $^{1}$ \\ ${ }^{1}$ Office of the Vice Chancellor, University of Eldoret, Eldoret, Kenya \\ ${ }^{2}$ Directorate of Research and Innovation, University of Eldoret, Eldoret, Kenya \\ ${ }^{3}$ Department of Chemistry, University of Eldoret, Eldoret, Kenya
}

Email address:

emmycheptoo@gmail.com (E. Kerich)

${ }^{*}$ Corresponding author

\section{To cite this article:}

Teresa Akenga, Emmy Kerich, Ayabei Kiplagat, Vincent Sudoi, Cyrus Kuya. Investigation of Selected Heavy Metal Ions in Irrigation Water, Soil and Managu (Solanum Nigrum) from Homahills, Homabay County, Kenya. Journal of Health and Environmental Research. Vol. 5, No. 4, 2019, pp. 101-106. doi: 10.11648/j.jher.20190504.12

Received: November 26, 2019; Accepted: January 16, 2020; Published: February 18, 2020

\begin{abstract}
Levels of selected heavy metals of $\mathrm{Mn}, \mathrm{Cd}, \mathrm{Pb}, \mathrm{Zn}, \mathrm{Fe}$ and $\mathrm{Co}$ were evaluated in irrigation water, soil and managu (Solanum Nigrum) from Homahills, Homabay County, Kenya. The samples were collected purposively and randomly then transported to KALRO Kericho to be analysed using Inductive Coupled Plasma Optical Emission Spectroscopy. Descriptive statistics and t-test analysis for the heavy metal concentrations were done using SPSS Version 21, transfer factor was also calculated. The levels of heavy metals detected in irrigation water were; $0.89,0.01,0.18,0.35,4.20$ and $0.04 \mathrm{mg} / \mathrm{L}$ for $\mathrm{Mn}, \mathrm{Cd}$, $\mathrm{Pb}, \mathrm{Zn}, \mathrm{Fe}$ and $\mathrm{Co}$ respectively. The overall concentration of heavy metals detected in soil under irrigation were; $315.56,1.00$, $13.00,19.17,59.05$ and $12.50 \mathrm{mg} / \mathrm{kg}$ for $\mathrm{Mn}, \mathrm{Cd}, \mathrm{Pb}, \mathrm{Zn}, \mathrm{Fe}$ and Co respectively. The overall levels of heavy metals detected in Solanum Nigrum under irrigation were 10.16, 5.23, 4.02, 41.42, 479.56 and $11.41 \mathrm{mg} / \mathrm{kg}$ for $\mathrm{Mn}, \mathrm{Cd}, \mathrm{Pb}, \mathrm{Zn}, \mathrm{Fe}$ and $\mathrm{Co}$ respectively. Using paired t-test, the mean heavy metals level recorded in irrigated Solanum Nigrum from two Sub locations were significantly different $(\mathrm{p}<0.05)$ in $\mathrm{Mn}, \mathrm{Pb}, \mathrm{Zn}$ and $\mathrm{Co}$ but not significantly different in $\mathrm{Cd}$ and $\mathrm{Fe}$. The results revealed that levels of $\mathrm{Cd}, \mathrm{Mn}, \mathrm{Fe}$ and $\mathrm{Pb}$ in soil and Solanum Nigrum were above the FAO/WHO limit. These levels pose risks to the consumers rendering them not safe for consumption. Therefore, regular monitoring for these metals in food is vital in ensuring consumption of safe food and avoiding bioaccumulation in the food chain.
\end{abstract}

Keywords: Heavy Metals, Bioaccumulation, Solanum Nigrum, Irrigation Water and Soil

\section{Introduction}

Soils is considered as the fine earth and are vital for life as they provide the medium for plant growth, home for many organisms, filter surface water among others [1,2]. Currently, due to increased development activities soil pollution has become a common occurrence. Some of the main sources of soil contamination consist of agricultural practices, industrial emissions or effluents and natural sources among others [3-6]. Polluted soil can be a major route of exposure of heavy metals to humans through uptake of polluted food crops and can cause in increased harm because of bioconcentration [7-9]. Vegetables grown on heavy metals polluted farmlands can take up the metals and prolong exposure of heavy metals even at very low concentrations can result in long lasting cumulative health effects in humans [10-12]. Concentration of heavy metals in leafy vegetables plants is influenced by parameters like the levels of heavy metals in soils, climatic condition of the region, the soil type, atmospheric depositions, and the extent of maturity of the plants during sampling [13, 14].

Elevated levels of cadmium causes cancer through DNA damage, kidney disease, teratogenic defects among others $[15,16]$. Zinc is known to cause damage to brain, respiratory track and increases the risks of prostate cancer [17, 18]. Copper is reported to cause developmental toxicity, liver and kidney damage among others $[19,20]$. Manganese can cause 
effect to development of human fetus and neurological damage [21, 22]. An elevated dietary iron intake increase risk of cancers [23, 24]. An elevated level of lead is known to impair neuro development in children, kidney damage, causes cancer through DNA damage, and death [16, 25, 26].

Water pollution by heavy metal is generally unavoidable in some areas because of natural environmental process such as volcanic eruption, weathering of rocks and human activities such as agricultural practices such as farming and industrial air and liquid effluents. Plants can take up heavy metals from soil especially in soluble form [27-30].

A research carried out by [31] on heavy metal in water, sediments and plants from Sosiani River, Uasin-Gishu County, Kenya reported 0.18 ppm, 0.46 ppm and 0.70 ppm of $\mathrm{Cu} \mathrm{Pb}$ and $\mathrm{Zn}$ respectively from the water collected and also reported elevated levels of $\mathrm{Zn}$ in the studied plants.

Heavy metals have a tendency to stay long in the environment and also bioaccumulate in food-chains. The leafy vegetables have a tendency to accumulate more heavy metals as compared to fruits and grains $[32,33]$. Food ingestion of heavy metals can cause long term body build up and its effects can only be felt after numerous years of exposure [34]. Consequently, consistent monitoring of heavy metals in the food especially leafy vegetables should be carried out in order to avert accumulation of heavy metals in the human food chain. Therefore, the present study was undertaken to assess the extent of toxic trace heavy metal in irrigation Water, Soil and Managu (SolanumNigrum) Homahills, Homabay County, Kenya.

\section{Methodology}

Homa Bay County lies within latitude of $0^{\circ} 54^{\prime} 08^{\prime}$ 'S and a longitude of $34^{\circ} 18^{\prime} 00^{\prime \prime E}$. It borders Migori Kisumu Siaya Kisii and Nyamira counties, Lake Victoria and Uganda. The county covers an area of $4,267.1 \mathrm{~km}^{2}$ inclusive of the water surface with geographical coverage of $1,160 \mathrm{~km}^{2}[35,36]$.

The study was conducted in Homahills which is situated about 50 kilometers north of Kendu Bay. The area which lies on the Nyanzan Rift covers an area of roughly $150 \mathrm{~km}^{2}$ and. The homahill has 6 kilometres in long axis and 5 kilometres in short axis with an evelation of 1571 metres above sea level. Homa hills area is characterized by black cotton soils and dark loam soils, which are derivatives of basalts, tuff, rhyolites and andesite [37-39].

The main economic activities are small-scale agriculture, fishing, trade and livestock keeping. The major crops grown in the region are maize, sorghum, sweat potatoes and millet both for domestic and trade purposes. The area is dominated by clay loam sandy soils derived from igneous rocks. The Bala hot spring also dominates the irrigated farms in some parts of Kauma and Kakdhimu location. The greater Lake Victoria is situated on the eastern parts next to Kendu-Bay all the way to Kakdhimu location [40].

\subsection{Experimental Procedures}

Two agro-ecological zones were purposively sampled, many residents in these zones were irrigating their crops using the water from the Lake. The two zones were Lower Midland 3 where Kanam B location falls and Lower Midland 4 Kokoth Kata location falls. Four farms in each sub-location were purposively sampled where irrigation of vegetables were practiced. A line transect was used to identify the sites where soil and vegetables samples were collected.

Two leaves of vegetables were plucked at maturity, inserted into khaki bags and transported to laboratory for preparation and analysis. The leaves were then cleaned with tap water and rinsed with distilled water to remove soil particles and other debris. It was then air dried and cut into small sizes and finally using a stainless grinder crushed into fine powder and placed in a well labeled khaki bags and stored for further analysis.

Composite soil samples were sampled from the depth of $(0-10$ and $11-15 \mathrm{~cm})$ in the same site where the vegetable plants were collected. The soil auger was used to collect approximately $0.5 \mathrm{~g}$ of soil samples and stored in dry well labeled khaki bags. The samples were collected in triplicate and a total of 18 samples were collected during the research. The collected samples were transported to University of Eldoret biotechnology laboratory where it was dried using an oven at a temperature approximately 90 degrees centigrade in order to eliminate the moisture and then using a stainless steel grinder grounded to fine powder. Then, the ground samples were placed in khaki bags awaiting digestions and analysis. The samples were finally taken to KALRO Kericho for digestion and analysis using inductive couple plasma.

Water which was used for irrigation in the selected three selected farms was sampled into $500 \mathrm{ml}$ clean glass vials using purposive sampling. The vials were labeled and a drop of $\mathrm{HNO}_{3}(65 \%)$ was added to make their $\mathrm{pH}<2$ to avoid precipitation of metals and stored at $5^{\circ} \mathrm{C}$ awaiting transportation to University of Eldoret labs and finally to KALRO Kericho for samples digestion. Nine samples were collected during the study.

\subsubsection{Vegetable Samples Digestion}

A $0.3 \mathrm{~g}$ of finely ground dried vegetable sample was weighed placed into separate pre-cleaned digestion tubes. A $4.4 \mathrm{ml}$ of the digestion mixture and reagent blanks were added to each tube. At $350^{\circ} \mathrm{C}$ the tubes were heated in a block digestor for 2 hours until it became colourless. Then the tubes were detached from the digester and it was left to cool at the normal room temperature. A $25 \mathrm{ml}$ of distilled water was then added, thoroughly mixed and topped up 50 $\mathrm{ml}$ with distilled water. The contents were then eventually transferred into a $50 \mathrm{ml}$ volumetric flask and left to settle. The clean solution was finally decanted to be used for analysis using ICP-OES.

\subsubsection{Soil Samples Digestion}

$2 \mathrm{~g}$ of each soil sample was bench dried for 5 days in the laboratory then crushed in a mortar with pestle to fineness. The ground soil sample was sieved through a 10-mesh (2 $\mathrm{mm})$ sieve and moisture dried in the oven separately at $105^{\circ} \mathrm{C}$ until constant weight was obtained. The wet digestion was done by reflux digestion of $1 \mathrm{~g}$ sub-sample with $10 \mathrm{ml}$ of 
concentrated $\mathrm{HCl} / \mathrm{HNO}_{3}$ in 1:4 ratios. A few boiling chips were added and temperature regulated at $100^{\circ} \mathrm{C}$ for 3 hours by using Aluminium digestion block. The mixture cooled and acid was added with $12.5 \% \mathrm{v} / \mathrm{v} \mathrm{HNO}_{3}$ then filtered (Mazira, 2012 and Salano, 2014). The samples were analyzed using ICP-OES using the standard procedure stipulated by the author in (Melaku et al., 2005).

\subsubsection{Water Digestion}

The samples were shaken in their vials, and then a $100 \mathrm{ml}$ was measured and transferred to a conical flask and digested on a hot plate using a mixture of conc $\mathrm{HNO}_{3} / \mathrm{HCl}$ until a light coloured clear solution was produced. $2 \mathrm{ml}$ of concentrated hydrochloric acid heated slightly to dissolve any remaining residue. Few drops of hydrogen peroxide was then added to ensure complete digestion. The solution was then diluted with distilled water to the mark and stored in refrigerator awaiting ICP-OES analysis (Cobbina, et al., 2015; Mazira, 2012; Du Plessis, 2015).

\subsection{Statistical Analysis}

Descriptive statistics and t-test analysis for the heavy metal concentrations ( $\mathrm{Mn}, \mathrm{Pb}, \mathrm{Cu}, \mathrm{Zn}, \mathrm{Co}, \mathrm{Fe}$ and $\mathrm{Cd}$ ) in irrigation water, soil, and vegetables were done using SPSS Version 21. Data were presented in tables and figures. Transfer factor was also calculated as follows $T F=C_{\text {plant }} / C_{\text {Soil }}$ Where $C_{\text {plant }}$ and $\mathrm{C}_{\text {soil }}$ represents the toxic metal concentration in extracts of plants and soils on dry weight basis, respectively.

\section{Results}

\subsection{Heavy Metal Concentrations in Water Used for Irrigation}

The mean levels of heavy metal $(\mathrm{mg} / \mathrm{L})$ of the irrigation water are shown in figure 1 . The highest recorded was $\mathrm{Fe}(4.20 \mathrm{mg} / \mathrm{L})$ and $\mathrm{Cd}(0.01 \mathrm{mg} / \mathrm{L})$ was the lowest concentration. The order of concentration (according to mean values of all areas) was $\mathrm{Fe}>\mathrm{Mn}>\mathrm{Zn}>\mathrm{Pb}>\mathrm{Co}>\mathrm{Cd}$ in the water.

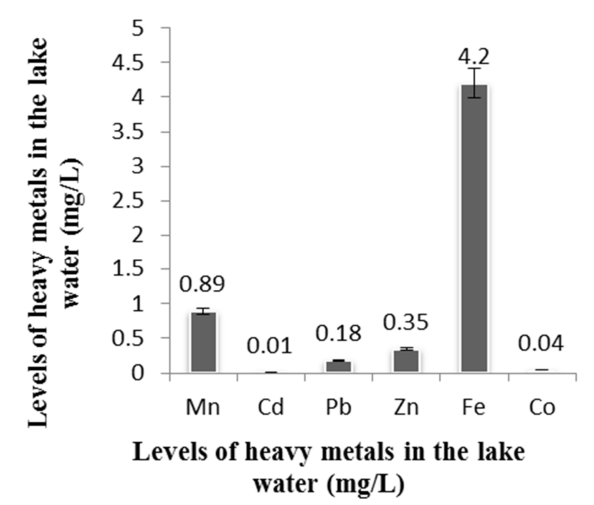

Figure 1. Heavy metals concentration in Irrigation Lake Victoria water from Homahills region.

The levels of heavy metals detected in water used for irrigation were; $0.89 \pm 0.58 \mathrm{mg} / \mathrm{L}$ for $\mathrm{Mn}, 0.01 \pm 0.00 \mathrm{mg} / \mathrm{L}$ for $\mathrm{Cd}, 0.18 \pm 0.08 \mathrm{mg} / \mathrm{L}$ for $\mathrm{Pb} 0.35 \pm 0.14 \mathrm{mg} / \mathrm{L}$ for $\mathrm{Zn}$,
$4.20 \pm 2.20 \mathrm{mg} / \mathrm{L}$ for Fe and $0.04 \pm 0.01 \mathrm{mg} / \mathrm{L}$ for Co.

\subsection{Heavy Metal Concentrations of Soil Found in Homahill, Homabay County}

\subsubsection{Heavy Metals Levels in Irrigated Soil from Kokoth Kata and Kanam B Sub Locations in Homahills}

$\mathrm{Mn}(315.56 \mathrm{mg} / \mathrm{kg})$ recorded the highest concentration while $\mathrm{Cd}(1 \mathrm{mg} / \mathrm{kg})$ had the lowest concentration. The order of concentration (according to mean values of all areas) was $\mathrm{Mn}>\mathrm{Fe}>\mathrm{Zn}>\mathrm{Co} \mathrm{Pb}>\mathrm{Cd}$ in the soil. Results are presented in table 1 below.

Table 1. The overall levels of heavy metals concentration found in the soil under irrigation in Kokoth Kata and Kanam B sub locations from Homahills region.

\begin{tabular}{lllll}
\hline & $\mathbf{N}$ & Mean & & Std. Deviation \\
\cline { 2 - 5 } & Statistic & Statistic & Std. Error & Statistic \\
\hline $\mathrm{Mn}$ & 18 & 315.56 & 13.59 & 57.64 \\
$\mathrm{Cd}$ & 18 & 1.00 & 0.00 & 0.00 \\
$\mathrm{~Pb}$ & 18 & 9.06 & 0.37 & 1.55 \\
$\mathrm{Zn}$ & 18 & 19.17 & 1.42 & 6.03 \\
$\mathrm{Fe}$ & 18 & 59.06 & 1.73 & 7.34 \\
$\mathrm{Co}$ & 18 & 12.50 & 0.19 & 0.79 \\
\hline
\end{tabular}

The overall levels of heavy metals detected in soil under irrigation were; $315.56 \pm 13.59 \mathrm{mg} / \mathrm{Kg}$ for $\mathrm{Mn}, 1.00 \pm 0.00$ $\mathrm{mg} / \mathrm{Kg}$ for $\mathrm{Cd}, 13.00 \pm 0.37 \mathrm{mg} / \mathrm{Kg}$ for $\mathrm{Pb}, 19.17 \pm 1.42$ $\mathrm{mg} / \mathrm{Kg}$ for $\mathrm{Zn}, 59.06 \pm 1.73 \mathrm{mg} / \mathrm{Kg}$ for $\mathrm{Fe}$ and $12.50 \pm 0.19$ $\mathrm{mg} / \mathrm{Kg}$ for Co.

The levels of heavy metals detected in soil under irrigation from Kokoth Kata were; $313.89 \pm 15.21 \mathrm{mg} / \mathrm{kg}$ for $\mathrm{Mn}, 1.00$ $\pm 0.00 \mathrm{mg} / \mathrm{Kg}$ for $\mathrm{Cd}, 7.89 \pm 0.20 \mathrm{mg} / \mathrm{Kg}$ for $\mathrm{Pb}, 15.00 \pm$ $0.37 \mathrm{mg} / \mathrm{Kg}$ for $\mathrm{Zn}, 58.56 \pm 2.96 \mathrm{mg} / \mathrm{Kg}$ for $\mathrm{Fe}$ and $12.11 \pm$ $0.26 \mathrm{mg} / \mathrm{Kg}$ for $\mathrm{Co}$.

The levels of heavy metals detected in soil under irrigation from Kanam B were; $317.22 \pm 23.50 \mathrm{mg} / \mathrm{Kg}$ for $\mathrm{Mn}, 1.00 \pm$ $0.00 \mathrm{mg} / \mathrm{Kg}$ for $\mathrm{Cd}, 10.22 \pm 0.43 \mathrm{mg} / \mathrm{Kg}$ for $\mathrm{Pb}, 23.33 \pm 2.03$ $\mathrm{mg} / \mathrm{Kg}$ for $\mathrm{Zn}, 59.56 \pm 2.96 \mathrm{mg} / \mathrm{Kg}$ for $\mathrm{Fe}$ and $112.89 \pm 0.20$ $\mathrm{mg} / \mathrm{Kg}$ for $\mathrm{Co}$.

\subsubsection{Spatial Comparisons of Heavy Metals Found in Soil from Kokoth Kata and Kanam B Sub Location}

Using paired t-test, the mean heavy metals level recorded in soil was $(\mathrm{p}<0.05)$ significantly different in $\mathrm{Pb}, \mathrm{Zn}$ and $\mathrm{Co}$ were $\mathrm{Pb}(\mathrm{P}=0.000, \mathrm{df}=8 \mathrm{~T}=-5.715), \mathrm{Zn}$ $(\mathrm{P}=0.003, \mathrm{df}=8 \mathrm{~T}-4.211)$ and $\mathrm{Co}(\mathrm{P}=0.043, \mathrm{df}=8 \mathrm{~T}=-2.401)$ respectively. However, paired t-test, the heavy metals mean level recorded was not significantly different $\mathrm{Mn}$ $(\mathrm{P}=.879, \mathrm{df}=8 \mathrm{~T}=-0.157)$ and $\mathrm{Fe}(\mathrm{P}=0.776, \mathrm{df}=8 \mathrm{~T}=-0.295)$.

\subsection{Heavy Metal Concentrations of Solanum Nigrum Found in Homahill, Homabay County}

\subsubsection{Heavy Metals levels in solanum nigrum from Kokoth Kata and Kanam B Sub Locations in Homahills}

Fe $(479.56 \mathrm{mg} / \mathrm{Kg})$ had the highest concentration and $\mathrm{Pb}$ $(5.2 \mathrm{mg} / \mathrm{Kg})$ recorded the lowest concentration. The order of concentration (according to mean values of all areas) was $\mathrm{Fe}>\mathrm{Zn}>\mathrm{Co}>\mathrm{Mn}>\mathrm{Cd}>\mathrm{Pb}>$ in the solanum nigrum. Results are 
presented in table 2 below.

Table 2. The overall levels of heavy metals concentration found in the Solanum Nigrum under irrigation in Kokoth Kata and Kanam B sub locations from Homahills region.

\begin{tabular}{llllll}
\hline & $\mathbf{N}$ & Mean & & Std. Deviation & Variance \\
\cline { 2 - 6 } & Statistic & Statistic & Std. Error & Statistic & Statistic \\
\hline $\mathrm{Mn}$ & 18 & 10.16 & 1.69 & 7.17 & 51.46 \\
$\mathrm{Cd}$ & 18 & 5.22 & 0.08 & 0.34 & 0.1 \\
$\mathrm{~Pb}$ & 18 & 4.02 & 0.23 & 0.99 & 0.99 \\
$\mathrm{Zn}$ & 18 & 41.42 & 4.16 & 17.63 & 310.90 \\
$\mathrm{Fe}$ & 18 & 479.56 & 19.8 & 84.04 & 0.01 \\
$\mathrm{Co}$ & 18 & 11.41 & 0.38 & 1.60 & 2.56 \\
\hline
\end{tabular}

The overall levels of heavy metals detected in Solanum Nigrum under irrigation were; $10.16 \pm 1.69 \mathrm{mg} / \mathrm{Kg}$ for $\mathrm{Mn}$, $5.22 \pm 0.08 \mathrm{mg} / \mathrm{Kg}$ for $\mathrm{Cd}, 4.02 \pm 0.23 \mathrm{mg} / \mathrm{Kg}$ for $\mathrm{Pb}, 41.42$ $\pm 4.16 \mathrm{mg} / \mathrm{Kg}$ for $\mathrm{Zn}, 479.56 \pm 19.81 \mathrm{mg} / \mathrm{Kg}$ for $\mathrm{Fe}$ and $11.41 \pm 0.38 \mathrm{mg} / \mathrm{Kg}$ for Co.

The levels of heavy metals detected in Solanum Nigrum under irrigation in Kokoth Kata Sub location were; $9.43 \pm$ $0.28 \mathrm{mg} / \mathrm{Kg}$ for $\mathrm{Mn}, 5.18 \pm 0.11 \mathrm{mg} / \mathrm{Kg}$ for $\mathrm{Cd}, 4.16 \pm 0.24$ $\mathrm{mg} / \mathrm{Kg}$ for $\mathrm{Pb}, 40.67 \pm 5.06 \mathrm{mg} / \mathrm{Kg}$ for $\mathrm{Zn}, 476.44 \pm 30.56$ $\mathrm{mg} / \mathrm{Kg}$ for $\mathrm{Fe}$ and $11.46 \pm 0.52 \mathrm{mg} / \mathrm{Kg}$ for Co.

The levels of heavy metals detected in Solanum Nigrum under irrigation in Kanam B Sub location were; $10.88 \pm 2.61$ $\mathrm{mg} / \mathrm{Kg}$ for $\mathrm{Mn}, 5.26 \pm 0.12 \mathrm{mg} / \mathrm{Kg}$ for $\mathrm{Cd}, 3.87 \pm 0.41$ $\mathrm{mg} / \mathrm{Kg}$ for $\mathrm{Pb}, 42.16 \pm 6.90 \mathrm{mg} / \mathrm{Kg}$ for $\mathrm{Zn}, 482.67 \pm 27.04$ $\mathrm{mg} / \mathrm{Kg}$ for $\mathrm{Fe}$ and $11.36 \pm 0.58 \mathrm{mg} / \mathrm{Kg}$ for $\mathrm{Co}$.

\subsubsection{Spatial Comparisons of Heavy Metals Found in Irrigated Solanum Nigrum from Kokoth Kata and Kanam B Sub Location}

Using paired t-test, the mean heavy metals level recorded Solanum Nigrum under irrigation was $(\mathrm{p}<0.05)$ significantly different in $\mathrm{Pb}, \mathrm{Zn}$ and $\mathrm{Co}$ were $\mathrm{Pb}(\mathrm{P}=0.000, \mathrm{df}=8 \mathrm{~T}=-5.715)$, $\mathrm{Zn}(\mathrm{P}=0.003, \mathrm{df}=8 \mathrm{~T}-4.211)$ and $\mathrm{Co}(\mathrm{P}=0.043, \mathrm{df}=8 \mathrm{~T}=-2.401)$ respectively. However, paired t-test, the heavy metals mean level recorded was not significantly different $\mathrm{Mn}(\mathrm{P}=0.402$, $\mathrm{df}=8 \mathrm{~T}=0.885)$ and $\mathrm{Fe}(\mathrm{P}=0.776, \mathrm{df}=8 \mathrm{~T}=-0.295)$.

\subsection{Transfer Factors of the Heavy Metals from Soil to Vegetables}

The calculated transfer factor for $\mathrm{Mn}, \mathrm{Cd}, \mathrm{Pb}, \mathrm{Zn}, \mathrm{Fe}$ and Co did not vary greatly in Kokoth Kata and Kanam B Location (Table 3).

Table 3. Transfer factor values for heavy metals obtained from Kokoth Kata and Kanam B location.

\begin{tabular}{lll}
\hline Heavy Metal & Kokoth Kata Transfer factor & Kanam B transfer Factor \\
\hline Manganese & 0.03 & 0.04 \\
Cadmium & 5.18 & 5.26 \\
Lead & 0.53 & 0.38 \\
Zinc & 2.711 & 1.81 \\
Iron & 8.14 & 8.105 \\
Cobalt & 0.96 & 0.88 \\
\hline
\end{tabular}

From table 3 it's observed that $\mathrm{Cd}, \mathrm{Zn}$ and $\mathrm{Fe}$ had the highest transfer factor compared to other elements with $\mathrm{Fe}$ having the highest and Mn having the lowest. The sequence of $\mathrm{TF}$ for the elements followed the decreasing order $\mathrm{Cd}>\mathrm{Fe}>\mathrm{Zn}>\mathrm{Co}>\mathrm{Pb}>\mathrm{Mn}$.

\section{Discussions}

The levels of heavy metals detected in irrigation water were $0.89,0.01,0.18,0.35,4.20$ and $0.04 \mathrm{mg} / \mathrm{L}$ for $\mathrm{Mn}, \mathrm{Cd}$, $\mathrm{Pb}, \mathrm{Zn}, \mathrm{Fe}$ and $\mathrm{Co}$, respectively. The World Health Organization [41] standard for heavy metals in water used for irrigation are $0.2,2,5,5,0.2,0.1 \mathrm{mg} / \mathrm{L}$ for $\mathrm{Mn}, \mathrm{Zn}, \mathrm{Pb}, \mathrm{Fe}$, $\mathrm{Cu}$ and $\mathrm{Cd}$ respectively. Therefore, only $\mathrm{Mn}$ concentrations were above WHO standards. The high levels of Mn could be due to weathering of rocks and erosion from homahill. It can also be attributed to agricultural activities in the region [42]. [43] in their study on heavy metals in Urban and Peri-Urban Farms in Eastern Nairobi, Kenya recorded the concentrations $(\mathrm{mg} / \mathrm{L})$ to ranged from 3.09-3.54, 0.01-0.03, 0.21-0.28, 4.798.07, 0.17-0.22 and 0.42-0.47 mg/L for $\mathrm{Mn}, \mathrm{Zn}, \mathrm{Pb}, \mathrm{Fe}, \mathrm{Cu}$ and Cd respectively. [44] Reported ranges of $\mathrm{Cd}(0.00-0.006$ $\mathrm{mg} / \mathrm{L})$ and $\mathrm{Pb}(0.012-0.088 \mathrm{mg} / \mathrm{L})$, in water used for irrigation in Dinapur, Varanas agricultural fields.

In this study the overall mean metal concentrations of heavy metals in the soils under irrigation were; 315.56, 1.00, 13.00, 19.17, 59.05 and $12.50 \mathrm{mg} / \mathrm{kg}$ for $\mathrm{Mn}, \mathrm{Cd}, \mathrm{Pb}, \mathrm{Zn}, \mathrm{Fe}$ and Co respectively. According to [41], the permissible limits for $\mathrm{Mn}, \mathrm{Zn}, \mathrm{Pb}, \mathrm{Fe}$, and $\mathrm{Cd}$ in soil are 300, 100, 60, 300 and 3 $\mathrm{mg} / \mathrm{kg}$ respectively. According to the results, only $\mathrm{Mn}$ exceeded the permissible limits for soil. [45] recorded an iron metal content in the soils ranging between $73.62 \mathrm{mg} / \mathrm{kg}$ to $226.39 \mathrm{mg} / \mathrm{kg}$ which was slightly higher than this study. [46] recorded the heavy metal average levels to be $55.16 \mathrm{mg} / \mathrm{kg}$ for Cd which was higher than this study. [47] reported 28.24 $\mathrm{mg} / \mathrm{kg}$ of $\mathrm{Zn}$ in agricultural soil in India.

The paired t-test heavy metals level recorded in soil was ( $p$ $<0.05$ ) significantly different in $\mathrm{Pb}, \mathrm{Zn}$ and $\mathrm{Co}$ were $\mathrm{Pb}$ from Kokoth Kata and Kanam B location. The difference can be attributed to different agricultural practices employed by farmers in each region and different distribution of different heavy metals types in parent rock and hence variations availability and uptake by plants in those regions.

The overall levels of heavy metals detected in Solanum Nigrum under irrigation were 10.16, 5.23, 4.02, 41.42, 479.56 and $11.41 \mathrm{mg} / \mathrm{kg}$ for $\mathrm{Mn}, \mathrm{Cd}, \mathrm{Pb}, \mathrm{Zn}, \mathrm{Fe}$ and $\mathrm{Co}$ respectively. According to [41], the permissible limit for $\mathrm{Mn}$, $\mathrm{Zn}, \mathrm{Pb}, \mathrm{Fe}$, and $\mathrm{Cd}$ in leafy vegetables are $0.2,60,0.3,48$ and $0.2 \mathrm{mg} / \mathrm{kg}$ respectively. Therefore, $\mathrm{Mn}, \mathrm{Cd}, \mathrm{Pb}$, and $\mathrm{Fe}$ exceeded the standards.[48] and [42] reported lower levels of Fe level of $54.05 \mathrm{mg} / \mathrm{kg}$ in Amaranthuscaudatus and $147.41 \pm 0.01 \mathrm{mg} / \mathrm{kg}$ in the Amaranthushybridus vegetables respectively. [46] reported levels of $\mathrm{Cu}, \mathrm{Pb}$ and $\mathrm{Cd}$ in vegetables from the contaminated area to range from 0.463 to $6.67,0.00$ to 1.47 and 0.00 to $0.71 \mathrm{mg} / \mathrm{kg}$ respectively. [49] recorded levels in the vegetable dry matter $(\mathrm{mg} / \mathrm{kg}$ dry matter) to range between $0.15-0.66 \mathrm{mg} / \mathrm{kg}$ for Cadmium, $1.6-9.82 \mathrm{mg} / \mathrm{kg}$ for copper; $3.75-18.64 \mathrm{mg} / \mathrm{kg}$ for manganese, $1.96-8.02 \mathrm{mg} / \mathrm{kg}$ for lead and $11.60-59.15$ $\mathrm{mg} / \mathrm{kg}$ for zinc. 
The paired t-test the mean heavy metals level recorded inirrigated Solanum Nigrum was $(\mathrm{p}<0.05)$ significantly different in $\mathrm{Mg}, \mathrm{Pb}, \mathrm{Zn}$ and $\mathrm{Co}$ from Kokoth Kata and Kanam B location. These variations may be ascribed to the physical and chemical nature of the soil of the farm sites, absorption capacities of heavy metals by vegetables, atmospheric deposition of heavy metals. It can also be attributed to partly to different geological distribution of parent rock and to different agricultural practices employed by farmers in each region.

The highest metal TF was $\mathrm{Cd}$, this could be attributed to a higher mobility of $\mathrm{Cd}$ with a natural occurrence in soil, and the low retention of $\mathrm{Cd}$ (II) in the soil than other toxic cations [50]. [51] recorded the TF of zinc and lead found from soil to plant Enhydrafluctuans and Oryza from Bangladesh to be 1.762 and 1.05 ; and 5.519 and 1.20 respectively.

\section{Conclusion and Recommendation}

The water used for irrigation obtained from Lake Victoria was polluted by $\mathrm{Mn}$ which exceeded the WHO standards for irrigation water, also the same applied to soil. The heavy metals in Solanum Nigrum which exceed the WHO standards were $\mathrm{Mn}, \mathrm{Cd}, \mathrm{Pb}$, and Fe. The high levels in Solanum Nigrum were attributed to partially active volcanic Homahill and agricultural practices employed by farmers. High $\mathrm{TF}$ were recorded in $\mathrm{Cd}, \mathrm{Zn}$ and $\mathrm{Fe}$ indicating that these metals are more easily transferred from soil to the edible parts of plants than ones with low transfer factor posing a health risks to the consumers. Therefore, the residents of these areas are in high health risks of toxic metal exposure. These levels pose risks to the consumers rendering them not safe for consumption. Therefore, regular monitoring for these metals in food is vital in ensuring consumption of safe food and avoids bioaccumulation in the food chain.

\section{References}

[1] Hartemink AE: The definition of soil since the early 1800s. In Advances in Agronomy. Volume 137: Elsevier; 2016: 73-126.

[2] Carter MR: Soil quality for sustainable land management. Agronomy journal 2002, 94: 38-47.

[3] Engwa GA, Ferdinand PU, Nwalo FN, Unachukwu MN: Mechanism and Health Effects of Heavy Metal Toxicity in Humans. In Poisoning in the Modern World-New Tricks for an Old Dog? Intech Open; 2019.

[4] Koskei S, Cheng Y, Shi W-1: Feasibility Studies of Soil Remediation for Kenya. American Journal of Life Sciences 2017, 5: 36-42.

[5] Cai L, Xu Z, Ren M, Guo Q, Hu X, Hu G, Wan H, Peng P: Source identification of eight hazardous heavy metals in agricultural soils of Huizhou, Guangdong Province, China. Ecotoxicology and Environmental Safety 2012, 78: 2-8.

[6] Żukowska J, Biziuk M: Methodological evaluation of method for dietary heavy metal intake. Journal of food science 2008 ,

\section{3: R21-R29.}

[7] Bhagure GR, Mirgane S: Heavy metal concentrations in groundwaters and soils of Thane Region of Maharashtra, India. Environmental monitoring and assessment 2011, 173: 643-652.

[8] Khan S, Cao Q, Zheng Y, Huang Y, Zhu Y: Health risks of heavy metals in contaminated soils and food crops irrigated with wastewater in Beijing, China. Environmental pollution 2008, 152: 686-692.

[9] Balkhair KS, Ashraf MA: Field accumulation risks of heavy metals in soil and vegetable crop irrigated with sewage water in western region of Saudi Arabia. Saudi journal of biological sciences 2016, 23: S32-S44.

[10] Ebong G, Etuk H, Johnson A: Heavy metals accumulation by Talinum triangulare grown on waste dumpsites in Uyo metropolis, Akwa Ibom State, Nigeria. J Appl Sci 2007, 7: 1404-1409.

[11] Oluyemi E, Feuyit G, Oyekunle J, Ogunfowokan A: Seasonal variations in heavy metal concentrations in soil and some selected crops at a landfill in Nigeria. African Journal of Environmental Science and Technology 2008, 2: 089-096.

[12] Peralta-Videa JR, Lopez ML, Narayan M, Saupe G, GardeaTorresdey J: The biochemistry of environmental heavy metal uptake by plants: implications for the food chain. The international journal of biochemistry \& cell biology 2009, 41: 1665-1677.

[13] Sharma RK, Agrawal M, Marshall FM: Heavy metal (Cu, Zn, $\mathrm{Cd}$ and $\mathrm{Pb}$ ) contamination of vegetables in urban India: A case study in Varanasi. Environmental pollution 2008, 154: 254263.

[14] Fritioff $\AA$, Kautsky L, Greger M: Influence of temperature and salinity on heavy metal uptake by submersed plants. Environmental pollution 2005, 133: 265-274.

[15] Bernard A: Cadmium \& its adverse effects on human health. Indian Journal of Medical Research 2008, 128: 557.

[16] Jaishankar M, Tseten T, Anbalagan N, Mathew BB, Beeregowda KN: Toxicity, mechanism and health effects of some heavy metals. Interdisciplinary toxicology 2014, 7: 60-72.

[17] Nriagu J: Zinc toxicity in humans. Encyclopedia of Environmental Health; Nriagu, J, Ed; Elsevier BV: Amsterdam, NL, The Netherlands 2007: 1-7.

[18] Mills CF: Zinc in human biology. Springer Science \& Business Media; 2013.

[19] Turnlund JR, Keyes WR, Kim SK, Domek JM: Long-term high copper intake: effects on copper absorption, retention, and homeostasis in men. The American journal of clinical nutrition 2005, 81: 822-828.

[20] Tamura T, Turnlund JR: Effect of long-term, high-copper intake on the concentrations of plasma homocysteine and $\mathrm{B}$ vitamins in young men. Nutrition 2004, 20: 757-759.

[21] Wood RJ: Manganese and birth outcome. Nutrition reviews 2009, 67: 416-420.

[22] Aschner JL, Aschner M: Nutritional aspects of manganese homeostasis. Molecular aspects of medicine 2005, 26: 353362 . 
[23] Choi J-Y, Neuhouser ML, Barnett MJ, Hong C-C, Kristal AR, Thornquist MD, King IB, Goodman GE, Ambrosone CB: Iron intake, oxidative stress-related genes (MnSOD and MPO) and prostate cancer risk in CARET cohort. Carcinogenesis 2008, 29: 964-970.

[24] Kabat GC, Cross AJ, Park Y, Schatzkin A, Hollenbeck AR, Rohan TE, Sinha R: Intakes of dietary iron and heme-iron and risk of postmenopausal breast cancer in the National Institutes of Health-AARP Diet and Health Study. The American journal of clinical nutrition 2010, 92: 1478-1483.

[25] Njagi JM: Assessment of Heavy Metal Concentration in the Environment and Perceived Health Risks by the Community around Kadhodeki Dumpsite, Nairobi county. 2014.

[26] Steenland K, Boffetta P: Lead and cancer in humans: where are we now? American journal of industrial medicine 2000, 38: 295-299.

[27] Hu Y, Liu X, Bai J, Shih K, Zeng EY, Cheng H: Assessing heavy metal pollution in the surface soils of a region that had undergone three decades of intense industrialization and urbanization. Environmental Science and Pollution Research 2013, 20: 6150-6159.

[28] Duruibe JO, Ogwuegbu M, Egwurugwu J: Heavy metal pollution and human biotoxic effects. International Journal of physical sciences 2007, 2: 112-118.

[29] Verma R, Dwivedi P: Heavy metal water pollution-A case study. Recent research in science and technology 2013, 5.

[30] Klavinš M, Briede A, Rodinov V, Kokorite I, Parele E, Klavina I: Heavy metals in rivers of Latvia. Science of the Total Environment 2000, 262: 175-183.

[31] Jepkoech JK, Simiyu GM, Arusei M: Selected heavy metals in water and sediments and their bioconcentrations in plant (Polygonum pulchrum) in Sosiani River, Uasin Gishu County, Kenya. Journal of Environmental Protection 2013, 4: 796.

[32] Abbas M, Parveen Z, Iqbal M, Riazuddin M, Iqbal S, Ahmed M, Bhutto R: Monitoring of toxic metals (cadmium, lead, arsenic and mercury) in vegetables of Sindh, Pakistan. Kathmandu University Journal of Science, Engineering and Technology 2010, 6: 60-65.

[33] Nabulo G, Oryem-Origa H, Diamond M: Assessment of lead, cadmium, and zinc contamination of roadside soils, surface films, and vegetables in Kampala City, Uganda. Environmental Research 2006, 101: 42-52.

[34] Orisakwe OE, Nduka JK, Amadi CN, Dike DO, Bede O: Heavy metals health risk assessment for population via consumption of food crops and fruits in Owerri, South Eastern, Nigeria. Chemistry central journal 2012, 6: 77.

[35] Okech Co: Impact Of Climate Variability On Surface Water Resources In Homa Bay County.

[36] Obonyo F, Maingi N, Githigia S, Ng'ang'a C: Prevalence, intensity and spectrum of helminths of free range pigs in Homabay District, Kenya. Livestock Research for Rural Development 2012, 24: 47-49.

[37] Akech NO, Masibo M, Olago DO: Mineral, Oil and Gas Resources. In Developments in Earth Surface Processes. Volume 16: Elsevier; 2013: 11-22.

[38] Instructors C, Obuoyo Mj, Odaro M, Odhiambo M: Nge 309:
Field Work Project Field Project Report.

[39] Bernard A, Antony O, Vincent A, John G, Ambusso W: 2DForward Modeling of Ground Magnetic Data of Homa-Hills Geo-Thermal Prospect Area, Kenya. International Journal of Science and Research (IJSR) 2014, 3: 94-101.

[40] Obadoh T: Assessing Challenges Faced By Sweet Potato Producers In Kabondo-Kasipul Sub County Of Homa Bay County In Improving Their Incomes. Great Lakes University of Kisumu, 2015.

[41] Joint F, Organization WH, Additives WECoF: Evaluation of certain food additives and contaminants: seventy-third [73rd] report of the Joint FAO/WHO Expert Committee on Food Additives. 2011.

[42] Akubugwo EI, Ude VC, Uhuegbu FO, Ugbogu O: Physicochemical properties and heavy metal content of selected water sources in Ishiagu, Ebonyi State-Nigeria. Journal of Biodiversity and Environmental Sciences 2012, 2: 21-27.

[43] Mathenge SG, Njoroge WG, Mutuku OM: Assessment of Selected Heavy Metals in Soil and Untreated Wastewater Used For Irrigation in Urban and Peri-Urban Farms in Eastern Nairobi City County, Kenya.

[44] Singh KP, Mohan D, Sinha S, Dalwani R: Impact assessment of treated/untreated wastewater toxicants discharged by sewage treatment plants on health, agricultural, and environmental quality in the wastewater disposal area. Chemosphere 2004, 55: 227-255.

[45] Akubugwo EI, Obasi A, Chinyere GC, Eze E, Nwokeoji O, Ugbogu EA: Phytoaccumulation effects of Amaranthus hybridus L grown on Buwaya refuse dumpsites in Chikun, Nigeria on heavy metals. Journal of Biodiversity and Environmental Sciences 2012, 2: 20-17.

[46] Yang J, Ma S, Zhou J, Song Y, Li F: Heavy metal contamination in soils and vegetables and health risk assessment of inhabitants in Daye, China. Journal of International Medical Research 2018, 46: 3374-3387.

[47] Venkatesha Raju K, Somashekar R, Prakash K: Spatiotemporal variation of heavy metals in Cauvery River basin. Proceedings of the International Academy of Ecology and Environmental Sciences 2013, 3: 59-75.

[48] Tsafe A, Hassan L, Sahabi D, Alhassan Y, Bala B: Evaluation of heavy metals uptake and risk assessment of vegetables grown in Yargalma of Northern Nigeria. J Basic Appl Sci Res 2012, 2: 6708-6714.

[49] Silva LS, de Luna Galindo IC, Gomes RP, Filla VA, Campos MCC, de Freitas L, de Oliveira IA, Marques KPP, de Souza ED, Cazzeta JO: Investigation of heavy metal accumulation in soil, water and plants in areas with intensive horticulture. Australian Journal of Crop Science 2019, 13: 192.

[50] Lokeshwari H, Chandrappa G: Impact of heavy metal contamination of Bellandur Lake on soil and cultivated vegetation. Current science 2006: 622-627.

[51] Sultana MS, Jolly Y, Yeasmin S, Islam A, Satter S, Tareq SM: Transfer of Heavy Metals and Radionuclides from Soil to Vegetables and Plants in Bangladesh. Soil Remediation and Plants: Prospects and Challenges 2015: 331-366. 